\title{
What Kind of Poetry Would a Syriac Manuscript- Thief Read about Oneself?
}

\author{
Anton Pritula \\ Leading Research Fellow, The State Hermitage Museum, St. Petersburg, \\ Russia \\ pritulanna@gmail.com
}

\begin{abstract}
In the modern period, numerous notes appeared within the colophons, aiming to protect a manuscript from potential thieves by addressing various curses to them. Some of those curses obtained a verse form, mainly forming quatrains, the most popular genre form, suitable for various kinds of notes. The paper discusses a such pieces - never studied of published so far - that were composed and written by a scribe named Hōrmīz, son of 'Abd al-Aḥad, who worked in the early 18th century in Kirkuk (Syriac Bèt $S l \bar{k} k)$,
\end{abstract}

\section{Keywords}

Hōrmīz, son of 'Abd al-Ahad - East Syriac tradition - Syriac poetry - manuscript production - stealing manuscripts - scribal notes - verse colophons - verse curses

In her fundamental work on the late East Syriac literary and manuscript tradition, Heleen Murre-van den Berg provided an example of a note within the colophon that aimed to protect a manuscript from potential thieves by addressing various curses to them. ${ }^{1}$ Such a type of scribal invocations is apparently very characteristic for the development of the Syriac colophons of the period. They had a place and a standardized form for expressing various thoughts and feelings. The scholar has provided six examples of such protective prayers for the manuscript within a colophon were found in the

1 H.L. Murre-van den Berg, Scribes and Scriptures. The Church of the East in the Eastern Ottoman Provinces (1500-1850), Eastern Christian Studies 21, Leuven, 2015, p. 140. 
manuscripts dates from 1586 to $185^{\circ}$, having pointed out that most of them come from the 18 th century. ${ }^{2}$

It is also no wonder that such statements have sometimes obtained a verse form. Poetry, constantly expanding its sphere of use, was often used for colophons, at least since the early Ottoman time. There are numerous examples of such form used by scribes by both Catholic and the traditionalist line of the East Syriac tradition. The earliest examples known to me, possibly being rather experimental in first place, were composed by 'Abdī̌šc of Gāzartā in the mid16th century. ${ }^{3}$ Since then they had a constant popularity, and are met in various types of manuscripts. ${ }^{4}$

At the same time, short poems, and quatrains in particular, became a popular form for shorter scribal notes. ${ }^{5}$ This short paper discusses such pieces that exemplify verse curses aiming to protect a manuscript from thieves.

The texts under discussion - neither published nor studied so far - are met in two manuscripts kept in the library of the Chaldean diocese of Kirkuk (Syr. Bèt $S l \bar{o} k)$. Both were written by the same scribe, namely by priest Hōrmìz, son of 'Abd al-Ahad, in early 18th century in Kirkuk. He was obviously very active in copying manuscripts, nine of them survive that were written between 1701 and 1733 mostly in Kirkuk. ${ }^{6}$

The first manuscript containing these quatrains is the Wardā hymnologic collection (ACK 00076$)^{7}$ written on 1st Tammuz, 2038 AG/1st July, 1727, as follows from the verse colophon (fol. $227 \mathrm{v}-228 \mathrm{v}$ ) that might have been composed by the scribe himself.

The second one, being a Hiùdrā (ACK Ooo27), was finished on 1st Kānūn Qdīm, 2043 AG/1st December, 1731 in the monastery of Mār Tahmazgard in

2 Ibid., p. 140, especially footnote 11.

3 See A. Pritula, "Abdīšō` of Gāzartā, Patriarch of the Chaldean Church as a Scribe", Scrinium: Journal of Patrology and Critical Hagiography, 15 (2019), pp. 297-320.

4 See, for instance, a verse colophon in manuscript of the Wardā hymnologic collection ACK 00076 (fol. 227v-228v) being discussed below.

5 See, for instance, A. Pritula, "Reading and Writing on Reading and Writing: Short Poetry on Flyleaves in a Manuscript of the Metrical Grammar (DCA 00065)", Scrinium: Journal of Patrology and Critical Hagiography, 16 (2020) (forthcoming).

6 This copyist is mentioned by Wilmshurst (See D. Wilmshurst, The Eccesiastical Organisation of the Church of the East, 1318-1913, CSCO, Subsidia 104, Louvain, 2000, pp. 172, 179). Some of them are available online, on vHMML; for instance, ACK ooo37, written in 1701; permanent link: <https://w3id.org/vhmml/readingRoom/view/13306o>; ACK ooo34, written in 1720; permanent link: <https://w3id.org/vhmml/readingRoom/view/133057>; ACK 00026, written in 1723; permanent link:<https://w3id.org/vhmml/readingRoom/view/133049>; ACK ooo3o written in 1733; permanent link: <https://w3id.org/vhmml/readingRoom/view/133053>.

7 Available on vнммL; permanent link: <https://w3id.org/vhmml/readingRoom/view/ $132803>$. 
Kirkuk (fol. 337v). ${ }^{8}$ The colophon has a passage meant to protect the manuscript from the thieves (fol. $338 \mathrm{v}$ ).

Both books have a set of quatrains written in the same hand on the flyleaves (see the table and the Appendix below). Three of them contain curses, whereas the last one (no. 4) is a verse invocation to pray about the scribe Hōrmīz. It is noteworthy that the scribe has incorporated different verses with his name inside the text of at least three manuscripts he wrote (ACK 00034, fol. 88v, 89r; ACK 00037 , fol. 382 r; ACK 00076 , fol. 227V-228v). Thus, there is no doubt that he had skills in versification, and the quatrains being discussed here were composed by Hōrmīz himself. This set of the poems is published and translated here below in the Appendix, following the order of ACK 00076 , that contains all the four pieces, as shown in the table.

The first quatrain (no. 1) that contains curses addressed to non-believers is absent from the later manuscript ACK 00027. Unlike all the other pieces in the set that are composed in the twelve-syllable meter, it is written in a seven-syllable one. This metrical difference and non-consistency in the sequence of the quatrains clearly indicates that they are independent, not forming a strophic poem. And - most important - this very piece appears in other manuscripts, at least, one of which is much earlier than the copies by Hōrmīz being discussed here. It is a Chaldean Diocese of Alqosh manuscript (DCA ooog6, fol. 108r) written in 1585 by 'Ațayyā of Alqosh, ${ }^{9}$ one of the most outstanding Syriac scribes of the late period, being also a poet. ${ }^{10}$ Besides, the quatrain is met, at least, in a Ḥūdrā in Qalb al-Aqdas Chaldean Church of Tell-Kaif (QACCT оoо3o, fol. 237r), written in $1914,{ }^{11}$ and also in a poetic anthology in the same collection (QACCT ooo69, fol. $115 \mathrm{r}$ ), written in $1825 .{ }^{12}$

In DCA ooog6, the poem is rendered exactly as in the one written by Hōrmīz, whereas the two later manuscripts give certain discrepancies (see the Appen$d i x$, no. 1). Such a variation proves that the piece was widely circulating. No wonder that it was incorporated in a series of other poems being discussed here.

8 Available on vнммL; permanent link: <https://w3id.org/vhmml/readingRoom/view/ $133050>$.

9 Available at vнмmL; permanent link: <https://w3id.org/vhmml/readingRoom/view/ $208321>$.

10 For instance, see: Wilmshurst, The Eccesiastical Organisation, pp. 114, 400-423; Pritula, "Abdīšōo of Gāzartā", pp. 311-314.

11 See the description in HMML legacy catalogue: <http://18.235.151.129/detail.php?msid= $135569>$.

12 See the description in HMML legacy catalogue: <http://18.235.151.129/detail.php?msid= $135608>$. The dating in this catalogue, $1723 \mathrm{AD}$, is not correct, since the colophon mentions 1825 as the date of its completing (fol. 114r). 
TABLE Quatrains written by Hōrmīz, son of 'Abd al-Aḥad

\begin{tabular}{|c|c|c|c|}
\hline $\begin{array}{l}\text { Order Incipit } \\
\text { number } \\
\text { of the } \\
\text { piece }\end{array}$ & & $\begin{array}{l}\text { ACK } \\
\text { ooo } 76 \text {, } \\
\text { fol. 229r; } \\
\text { order } \\
\text { number } \\
\text { of the } \\
\text { piece }\end{array}$ & $\begin{array}{l}\text { ACK } \\
\text { ooo27, } \\
\text { fol. } 34 \text { or; } \\
\text { order } \\
\text { number } \\
\text { of the } \\
\text { piece }\end{array}$ \\
\hline 1 & 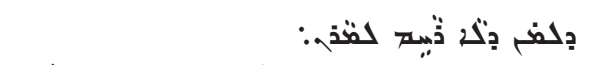 & 1 & - \\
\hline 2 & 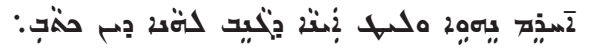 & 2 & 3 \\
\hline 3 & جُنتح دِّبت & 3 & 1 \\
\hline 4 & 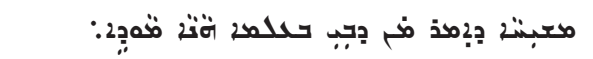 & 4 & 2 \\
\hline
\end{tabular}

The two quatrains that contain curses addressed to the thieves (no. 2, 3) mention different personalities from the Holy Scriptures, who either subjected to torture like leprosy in the earthly life, or are believed to be condemned to permanent suffering in the eternal life. To the first category Naaman (no. 2) and Gehazi (no. 2, 3) belong, who are both mentioned in 2 Kings 5 as suffering of leprosy. ${ }^{13}$ The latter was probably a rather popular as a sample of an affliction to this disease, since he is mentioned also in the protective prayer in the manuscript quoted by Murre-van den Berg. ${ }^{14}$ The second category includes Cain (see no. 2) and Judas Iscariot (see no. 3), the most famous cursed persons from the Bible.

As follows from the examples discussed above, the prayers for protecting books from thieves - much more often in prose than in verse - were rather popular in the East Syriac manuscript production of the modern time. A natural question emerges, how often book-stealing actually happened. Unfortunately, we have not collected any database of such records, and can only provide an example of such a note.

The manuscript DCA ooo23 was written in 1722 in Alqosh for the churches Mār Gīwargīs and Mār Mīkhā in Alqosh (see fol. 78v), and now belongs to the

13 Naaman was a general of the king of Aram, who suffered of leprosy, and was healed by Elisha's command to him to deep himself seven times in the Jordan river. Gehazi was Elisha's, who got leprous for his reproaching the prophet for being 'to easy on Naaman this Aramean' (2 Kings 5).

14 Murre-van den Berg, Scribes and Scriptures, p. 140. 
library of the Chaldean diocese of this town. ${ }^{15}$ Containing the rite of the Palm

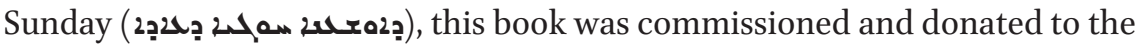
churches of Mār Gīwargīs and Mār Mīkhā in Alqosh by Šmūnī, mother of the priest Hadbšabbā, as the colophon says (fol. 77v-79r).

Right after the colophon, on the same folio (fol. 79r) there is a note by deacon Nīsān:

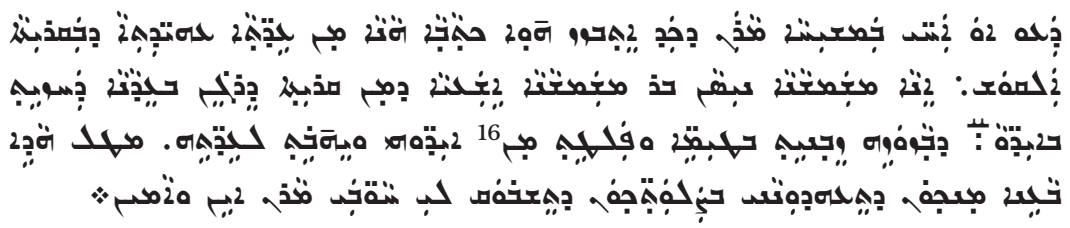

Know, o my brothers in Christ, our Lord, that after this book had been stolen from the above mentioned Churches ${ }^{17}$ in the village of Alqosh, I, deacon Nīsān, son of deacon Isaiah from the village of Dergen ${ }^{18}$ - as I saw $\mathrm{it}^{19}$ in the hands of the robber - payed ransom for it, saved it from his hands, and gave it back to these churches. Because of that, I ask you to mention me in your prayers so that the Lord will absolve my sins, verily, amen.

First, it is noteworthy, but apparently rather common for the period that the manuscript was commissioned and belonged to two churches. Obviously, they were located close to each other, and might have had a mutual library. We don't know how common stealing manuscripts in the North Iraq region was at that period, but the tone of the note sounds like something usual, at least not like an extraordinary event. The term used for the stealers is different from the one used in the poems discussed. In the quatrains, means 'thieves', whereas the note in DCA 00023 uses the word 2909 'robber, spoiler'. It is not quite clear if this choice of the lexics is occasional or it was determined by the character of the theft they had committed. The latter could have robbed the whole church or its library, and the former possibly just stole that very manuscript. Interestingly, a corresponding passage in the colophon

15 Available on vнммL; permanent link: <https://w3id.org/vhmml/readingRoom/view/ $128678>$.

16 بִ written over the line.

17 I.e. the churches of Mār Gīwargīs and Mār Mīkhā.

18 Possibly the same village as Dirginni in the region of 'Amādīyā, mentioned by Wilmshurst (Wilmshurst, The Eccesiastical Organisation of the Church of the East, pp. 132, 133, 135, 139, 150).

19 I.e. the manuscript. 
of DCA 00027 also contains a protective invocation (fol. $338 \mathrm{v}$ ) that uses both terms:

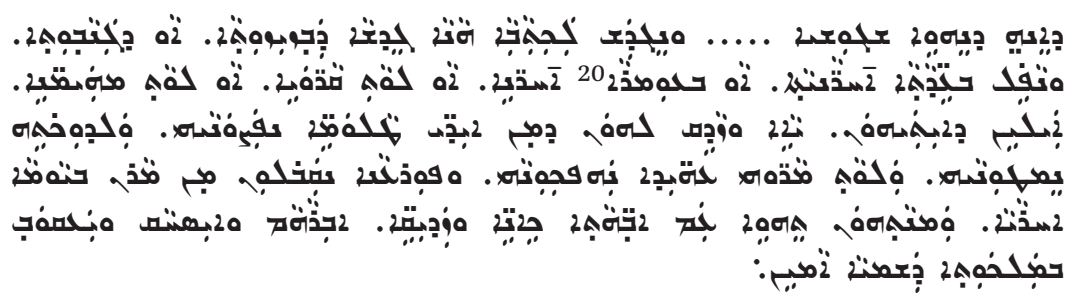

And verily, if a tumult happens ... and this book becomes a subject of robbery, or theft, or gets to other churches or to other cloisters, or to readers, or to believers. Whoever they are, it is appropriate and suitable to them to save it from the hands of the oppressors, and to give it back to the above-mentioned fathers. And they will receive a reward from our Lord on the last day, and their share will be with the righteous and just fathers Abraham, Isaak and Jacob in the kingdom of Heaven, amen.

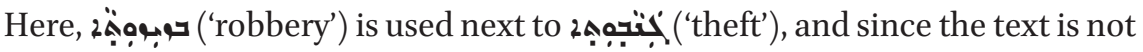
a poem, but rather a document statement, it seems to confirm such a differentiation of the terms. Besides, a reward in the heaven promised to a person, who would give the manuscript to the owning church is apparently one more confirmation of a wide spread of stealing manuscripts in the period. All the abovementioned and discussed statements, notes and records were meant to work as means of the protection from numerous thieves and robbers. Since the role of poetry in the Syriac tradition was constantly increasing during the Islamic period, it is not astonishing that it was also used in the manuscript-protecting activities. Verse form clearly makes these 'protective' notes sound stronger, and also emphasizes their significance, since such curses are much more noticeable in quatrains than in lengthy colophons that very few people would read. Scribes, who were at the same time clerics of the local churches were very much interested to contribute to that protective text corpus, and being also poets, had necessary skills for creating new verse pieces.

20 Obviously, a typo; should be: בحبم 20 


\section{Appendix}

[Quatrains written by Hōrmīz, son of 'Abd al-Aḥad: text and translation] ACK 00076 , fol. 229r

ACK 00027 , fol. 34 or

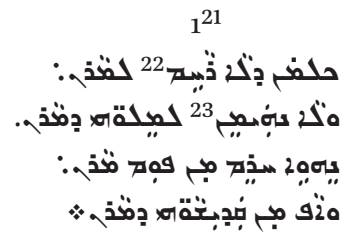

The one who dos not love our Lord, and does not believe in the word of our Lord, may he be banned by the mouth of our Lord, and by the saints of our Lord.

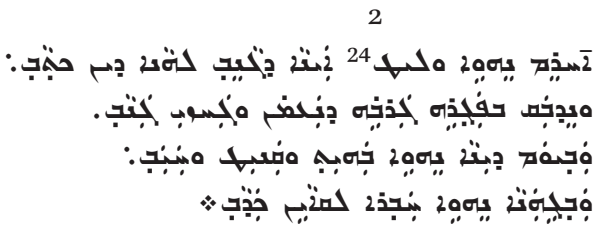

Banned be a cursed one, who will steal this book.

And may the leprosy of Naaman and Gehazi the thief touch him.

And on the day of the Judgment may he be ashamed, scared and accused. And may he be companion of Cain the deceiver.

3

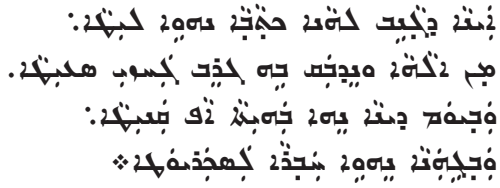

\footnotetext{
This quatrain is met also in QACCT Oo०3o (fol. 237r) and QACCT ooo69 (fol. 115r).

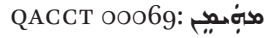

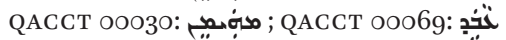
ACK 00076 o added over the line.
} 
The one who would steal this book, be cursed by God! And may the leprosy of ignoble Gehazi touch him! ${ }^{25}$ And may he be ashamed and scared on the day of the Judgment! And may he become a companion of Iscariot in Gehenna.

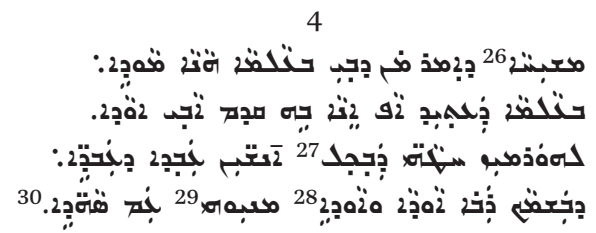

Christ, who said: 'He who will confess me in this world, I will confess him in the world to come before my Father', ${ }^{31}$ Hōrmīz - my sins are such [that I am] a servant of the servants of all people, who confessed and does confess your great name, count him among the martyrs!

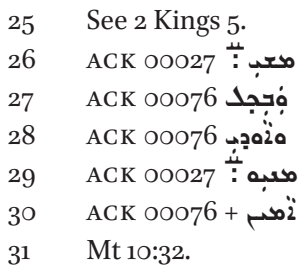


